\title{
NEW TRENDS IN THE CHANGES OF ADMINISTRATIVE BOUNDARIES IN POLAND
}

\begin{abstract}
The objective of the study is to determine the leading trends in changing administrative boundaries in Poland. Based on 194 Regulations of the Council of Ministers concerning the changes of boundaries and granting city status, which covered a total of $1,383.8 \mathrm{sq} . \mathrm{km}$, multidimensional analyses for the years 2010-2020 were conducted, and their results were referred to territorial reforms in Europe and Poland. The analyses provided the basis for selecting the leading trends, including: (1) the 'new wave' of the restitution of city status (from 2018 in the new fast-track mode), resulting in quantitative changes within $3^{\text {rd }}$-tier units, (2) a significant increase in the area of cities and city counties primarily caused by annexations in suburban zones and establishing new cities, and (3) the politicisation of the process of changing boundaries, especially in the years preceding local government elections. The trend of unit fragmentation observed in the 1990s has disappeared. The initiators of the changes of administrative boundaries are still predominantly local elites and rarely the inhabitants of communes. Key words: boundary changes, administrative boundaries, territorial reform, administrative division, commune, county, voivodeship, Poland.
\end{abstract}

\section{INTRODUCTION}

Changes in the territorial organisation of units result from territorial reforms or bottom-up initiatives (Baldersheim and Rose, 2010; Ebinger et al., 2019; Kaczmarek, 2005). The current experience shows that approaches in this scope have evolved, as reflected in consolidation reforms based on the trust in the "economies

* Dagmara KOCIUBA, Maria Curie-Sklodowska University in Lublin, Faculty of Earth Sciences and Spatial Management, Department of Spatial Management, Al. Kraśnicka 2d, 20-718 Lublin, Poland; e-mail: dagmara.kociuba@umcs.pl; ORCID: https://orcid.org/0000-0001-9217-323X

(c) by the author, licensee Łódź University - Łódź University Press, Łódź, Poland. This article is an open access article distributed under the terms and conditions of the Creative Commons Attribution license CC-BY-NC-ND 4.0 (https://creativecommons.org/licenses/by-nc-nd/4.0/) 
of scale' (1960s and 1970s) (Blom-Hansen et al., 2014), 'Europe of the Regions' (early $21^{\text {st }}$ century) (Magone, 2003), or countering the effects of the economic crisis (after 2009) (Steiner et al., 2016). Researchers have also observed territorial fragmentation resulting from decentralisation reforms in post-socialist countries in the 1990s (Baldersheim and Rose, 2010; Swianewicz, 2002). In Europe, a quantifiable effect of these reforms was the reduction of the number of local government units by 14,200 in the years 1990-2018 (Swianewicz, 2020).

It should also be emphasised that changes in the territorial organisation of units consist not only of modifying their numbers either through reduction or increase. The distribution of administrative boundaries established as the result of territorial reforms is often further modified in subsequent years due to both top-down and bottom-up initiatives. Such changes can take various forms, dependent on geographic, social, and economic conditions, as well as on the adopted legal solutions. They can cover units of different tiers. Such modifications can consist of establishing new, abolishing existing or merging or dividing entire units or their fragments (Carr and Feiock, 2016; Hardy, 2012; Holzer et al., 2009; Kaczmarek, 2005, 2016; Kachniarz, 2016; Szmytkie and Krzysztofik, 2019).Territorial reforms implemented in Poland have generally reflected European trends. The issue has been broadly discussed in the literature (Chojnicki and Czyż, 2000; Kaczmarek, 2001; Kulesza, 1997; Służewski, 1977). It is worth emphasising that the majority of the analyses have been conducted at the level of communes (gmina) (Kaczmarek, 2016; Walczak, 2012), seldom counties (powiat) (Swianewicz et al., 2016) or regions/provinces (voivodeship - województwo) (Miszczuk, 2003; Janicki, 2020). Studies usually focus on already amalgamated (Swianewicz and Szmigiel-Rawska, 2020) or split units (Swianewicz et al., 2016; Swianewicz et al., 2018). A clear research trend has also developed regarding the processes of territorial integration and disintegration of urban areas (Jarczewski, 2002; Kociuba, 2019; Krzysztofik and Dymitrow, 2015; Szmytkie, 2014; Szmytkie and Krzysztofik, 2019) and new cities (Drobek, 2020; Konecka-Szydłowska et al., 2018; Krzysztofik and Dymitrow, 2015; Liszewski et al., 1989; Sokołowski, 2014; Szymańska, 1993). Less attention is paid to changes in the boundaries of parts of units and related studies usually apply to the territorial expansion of cities (Kociuba, 2019; Rajchel, 2018) or counties (Swianewicz et al., 2016). Nonetheless, the majority of changes in the course of boundaries, particularly those of rural communes and smaller units due to their local character, is largely neglected and only mentioned in local and regional press. Other hardly investigated issues include changes in the administrative-territorial status and the area of units subject to boundary adjustment at the scale of the entire country (Kociuba, 2019), as well as new formal-legal procedures introduced in recent years, and the effects of their implementation. There is a general lack of studies that comprehensively discuss the changes in administrative boundaries, and analyse the regularities and trends in this scope.

The aim of the article is to fill this research gap. The objective of the study is to determine the leading trends in changing administrative boundaries in Poland. 
Starting from the presentation of the rationale and the effects of territorial reforms in Europe and Poland, further chapters discuss the main aspects of the issue:

1) legal and procedural conditions for changes in LGU boundaries and the granting of city status to localities and new regulations in this area;

2) the results of the changes in LGU boundaries in the 2010-2020 in terms of: territorial-administrative status and the area of units covered by a change, the cyclical character of changes, as well as the establishment of new cities;

3) main mechanisms of the transformation of the existing administrative-territorial structure, the interactions between units covered by boundary changes and the dominant tendencies in this scope.

These conducted analyses have identified several dominant trends and regularities, which were addressed in the discussion.

The study was conducted based on a thorough analysis of scientific publications, as well as legal acts and government decisions regarding the changes in the administrative boundaries of LGUs. It employed the methods of meta-analysis, query search, and information screening. The desk research method was used in the multi-dimensional analyses of the effects of the changes in administrative LGU boundaries. To present the scale of the phenomenon, the analyses were conducted both in the horizontal (units of the same tier) and vertical (hierarchical) systems. The source materials included the Regulations of the Council of Ministers (hereinafter: CM) on establishing the boundaries of certain communes and cities, granting city status to certain localities, as well as abolishing or changing the administrative status of cities and communes in 2009-2019. The analysis covered a total of 194 decisions of the $\mathrm{CM}$ regarding the changes of LGU boundaries. The data was supplemented based on justifications and drafts of justifications to regulations of the CM (http://isap. sejm.gov.pl/isap.nsf/, https://archiwumbip.mswia.gov.pl/bip), documentation related to the change of administrative LGU boundaries, and press releases. Illustrating the scale of the discussed phenomena in reference to the changes in administrative area, and in the case of new cities also population, employed data obtained from the resources of Statistics Poland (www.stat.gov.pl).

\section{THE RATIONALE AND THE EFFECTS OF TERRITORIAL REFORMS IN EUROPE AND POLAND}

\subsection{Territorial reforms in Europe}

Consolidation reforms in the 1960s and 1970s were implemented both in Western European countries (e.g. in the Scandinavia, the Great Britain, the Netherlands, and Western Germany) and in Central and Eastern European countries (Hungary, Czechoslovakia, Yugoslavia, Romania, and Poland). They resulted in the reduc- 
tion of the number of administrative-territorial units at all tiers (Steiner et al., 2016). The reforms of the 1990s introduced under decentralisation measures more frequently resulted in the division of existing units. That was particularly evident in post-socialist countries as a manifestation of the 'abreaction' to the forced consolidations in the 1970s (Baldersheim and Rose, 2010; Swianewicz, 2010), and it led to a considerable increase in the number of communes (quadrupled in Croatia and Macedonia, tripled in Slovenia, and doubled in Hungary) (Swianewicz, 2010).

At the beginning of the $21^{\text {st }}$ century, new consolidation reforms were implemented. On the one hand, they constituted an attempt to adjust to better absorb European funds in the "Europe of the Regions" (Magone, 2003), and, on the other hand, they constituted a response to the global economic crisis. They were implemented on a one-off basis (e.g. Iceland, Latvia, (Northern) Macedonia, Denmark, Ireland, Albania, Estonia, France, and Norway) or gradually (e.g. Great Britain, Greece, The Netherlands, and Finland) by at least 19 European countries (Swianewicz, 2020). Although most changes have recently involved territorial mergers, splits of units have also occurred, often as a result of bottom-up initiatives (Ebinger et al., 2019). Fragmentation was observed in at least 10 European countries, to the greatest degree in Romania, and less so in Slovenia, Spain, the Czech Republic, Slovakia, and Croatia (Swianewicz, 2020). Territorial reforms have led to changes in the number of administrative units, especially at the local level. Analyses conducted for 40 European countries have shown that consolidation reforms have resulted in a systematic decrease in the total number of communes that reached 116,000 in 1990. The decentralisation reforms in Central and Eastern Europe caused the number of communes to increase to 120,000 in 1994 . The consolidation reforms at the beginning of the $21^{\text {st }}$ century caused another decrease in the number of communes to 114,500 in 1998 and 101,800 in 2018 (Ladner et al., 2019; Swianewicz, 2020).

Changes in administrative division are usually of a horizontal character - they consist of fragmentation or consolidation of units of the same tier into larger territorial structures (Hardy, 2012; Holzer et al., 2009; Kachniarz, 2016). This results from the fact that the protection of boundaries, particularly at the local level, is rarely guaranteed by the constitution. This enables the governments of most countries to make decisions in the scope of both complex and unitary changes of administrative division, including the establishment and abolition of communes, and the modification of their boundaries. They are usually implemented based on a regular act (e.g. Bulgaria, Albania, and Portugal) or legal acts of governmental administration (regulations) (Poland) (Kaczmarek, 2005, 2016).

\subsection{The changes in the structure of territorial division in Poland}

The changes to the structure of territorial division units in Poland generally did not differ from the trends observed in Europe. Consolidation intensified in the 1970s for the purpose of creating strong units. As a result of the reform implemented in the 
1973-1975 period, the three-tier division from the pre-war period of 17 voivodeships (+ 5 cities with voivodeship status), 314 counties, 78 cities with county status, and 4,315 gromadas ${ }^{1}$ was replaced with a two-tier division. 49 voivodeships were designated, counties that had been functioning for over 400 years were abolished, and instead of 4,315 gromadas, 2,366 considerably larger collective communes were introduced ${ }^{2}$, divided into auxiliary units called 'sołectwo'. As a result of numerous amalgamations, exemplified by activities conducted in Silesia (Jarczewski, 2002), or development or conglomerate cities (Szmytkie, 2014), the number of communes decreased to 2,129 by 1976, and 39 cities were repealed (lost administrative independence) (Służewski, 1977). Such activities provided the basis for the administrative division of the country at the local level. The consolidation reform also inhibited the process of granting city status to localities, which intensified in the 1950s and 1960s and particularly concerned new cities established due to planned industrialisation. The consolidations at a much smaller scale continued in the 1980s. The number of cities slightly increased as a result of granting, or more frequently, restitution of city status to 22 localities.

The system transformation in the early 1990s brought a shift of public administration based on the rules of decentralisation and development of local self-government. The introduction of the Act of 8 March 1990 on Local Self-Government (since 1 January 1999, the title has been "Act on Commune Self-Government) (Journal of Laws 1990 No. 16 Item 95, as amended), pointing to commune councils as the primary initiators of the changes of boundaries, in combination with an increase in the sense of local autonomy expressed in the need of self-determination and independence, led to numerous divisions particularly recorded in the first half of the 1990s (Kaczmarek, 2016; Swianewicz et al., 2016). Some were related to a change of the status of units because the act abolished the division into cities and rural communes, and introduced the commune as the main administrative unit at the local level ${ }^{3}$. In 1992, after the completion of the process of the changes related to the implementation of the act, instead of 830 cities and 2,121 rural communes (state as at 1 January 1990), the number of communes stabilised at a level of 2,459 (299 urban communes, 535 urban-rural commune, and 1,625 rural communes). Two trends were observed in the process of the fragmentation of communes. On the one hand, urban-rural communes

\footnotetext{
${ }^{1}$ Gromadas were established based on the reform of 1954 as units of administrative division replacing rural communes. 3,001 communes were replaced with 8,789 gromadas covering several villages and hamlets.

${ }^{2}$ Until 1990, the term 'commune' ('gmina') was applied exclusively in reference to rural communes. Moreover, new cities were designated, i.e. units which were granted city rights.

${ }^{3}$ The applied division includes: urban communes, i.e. those containing cities in their administrative boundaries; urban-rural communes which include a city and several to a dozen villages and hamlets; rural communes which include no cities in their territory, although their seat may be located in a neighbouring urban commune (the so-called bagel communes). The division was not introduced in the act as a consequence of the coherence of system solutions in the scope of the legal status of the local government unit that is not subject to change. The differences consist of the names of administrative bodies (Sobota et al., 2012).
} 
disintegrated (23 in 1991). On the other hand, parts of communes, often previously forced to consolidate in the 1970s and 1980s, detached from the existing territorial-administrative units. This particularly concerned cities located in the Upper Silesian agglomeration, where cities and sometimes rural communes were established, or more frequently resituated (Jarczewski, 2002). Moreover, the trend of granting city status to localities intensified (50 decisions were issued in the 1990 s, including 41 on restitutions). It did not affect the total number of communes, but altered the number of self-government units of particular types at the local level.

The development of territorial self-government resulted in the need for a new reform of the territorial organisation of the country. It was completed in 1998 (Journal of Laws 1998 No. 96 Item 603), and restored the three-tier division: commune-county-province/voivodship (gmina-powiat-województwo), implementing the rules of decentralisation and territorial self-government. 16 voivodeships were established $\left(1^{\text {st }}\right.$ tier$)$, as well as 373 self-governmental units of administrative division of the $2^{\text {nd }}$ tier, i.e. 308 counties (powiat, pl. powiaty) and 65 city counties (cities with county status - miasta na prawie powiatu) (Journal of Laws of 1998 No. 103, Item 652). That state generally reflected the situation before the 1975 reform. In 2002, it was modified through restoring 7 powiats, and the establishment of the Warsaw county comprising 12 communes (including the city of Wesoła incorporated into Warsaw), then transformed into a city county. In the following year, the Wałbrzych city county was eliminated and incorporated into the Wałbrzych county. Fragmentation of $2^{\text {nd }}$ tier units in the 2002-2003 resulted in an increase in their number to 379, including powiats to 314. The implementation of the 1998 reform inhibited the tendencies of fragmentation of communes. In 1999 in Poland, there were 2,489 communes (including 307 urban communes, 567 urban-rural communes, and 1,615 rural communes). As a result of the elimination of Warsaw rural communes in 2002, the number of communes decreased to 2,478 , and remained at that level until 2009 . The process of granting city status also decelerated (in the 2000s, 23 decisions were issued, including 21 on restitutions).

\section{THE FORMAL-LEGAL AND THE PROCEDURAL ASPECTS OF THE CHANGES OF ADMINISTRATIVE BOUNDARIES}

\subsection{The formal-legal aspect}

In Poland, as in most other countries, the protection of unit boundaries is not guaranteed by the constitution ${ }^{4}$. Pursuant to Art. 4 of the Act of 8 March 1990

\footnotetext{
${ }^{4}$ As stated in the Constitution of the Republic of Poland of 2 April 1997 (Journal of Laws 1997 No. 78, item 483, as amended), the "basic unit of territorial local government is the commune (Art. 164(1)), therefore, constitutional guarantees concern only the institution of local self-government and not the spatial framework of its operation.
} 
on Local Self-Government (Journal of Laws 1990 No. 16, Item 95, as amended) and Art. 3 of the Act of 5 June 1998 on county self-government (Journal of Laws 1998 No. 91, Item 578, as amended), the Council of Ministers is entitled to apply changes to the territorial division of the state. Based on its annually regulations, the $\mathrm{CM}$ can, among others, establish, merge, divide, and abolish municipalities/ counties, and determine their boundaries, as well as grant city status to localities. The Council of Ministers issues an appropriate regulation by 31 July each year. The changes come into force on 1 January of the following year. The procedure of the submission of applications and documents required in such cases is stipulated by the Regulation of the Council of Ministers of 9 August 2001 (Journal of Laws No. 86, Item 943) and its amendment published in the form of an announcement of the Prime Minister (Journal of Laws 2014, Item 310).

A decision by the CM should consider two basic premises. The first one is the provision of maximum uniformity and territorial cohesion resulting from the analysis of the settlement and spatial layout in the context of social, economic, and cultural bonds. The second states that a commune/county in its new boundaries should be able to perform public tasks. A change of boundaries is determined by: the proper resources of social and technical infrastructure, urban layout, and the nature of building development. The $\mathrm{CM}$ does not issue a permit if the new unit does not meet the following criteria: (1) the revenue criterion, i.e. tax revenue per inhabitant is lower than the lowest tax revenue per inhabitant determined for particular communes pursuant to the The Act of 13 November 2003 on revenues of territorial self-government units (Journal of Laws 2003 No. 203, Item 1966, as amended), and (2) the population criterion, i.e. the new unit is smaller than the smallest unit in terms of the number of inhabitants of a commune in Poland as of 31 December of the year preceding the announcement of the regulation. In the case of granting a locality the city status, determination of its boundaries, and their change, the legislator additionally ensures for them to be implemented in a way which considers the social and technical infrastructure, as well as the urban layout and nature of building development.

\subsection{The procedures of the changes of LGUs boundaries}

A change of the administrative boundaries of an LGU in most cases involves an application procedure. The application for a change of boundaries is submitted by the council of a commune/county/city county after conducting consultation with residents. By 31 March of each year, the council, with the intermediation of the voivode, submits an application to the Minister of Internal Affairs and Administration (hereinafter: MIAA) who submits it together with recommendations to the $\mathrm{CM}$. The CM makes the final decision with consideration for statutory requirements and mutual consent between units covered by boundary changes, and issues a relevant regulation. Other less popular procedures include: 
- a ministerial procedure that requires a consultation of the MIAA with interested municipal councils,

- a merger procedure (initiated by the voivode). Since 2003, the procedure has had financial support of the state in the form of a so-called 'ministerial bonus', i.e. a 5 percent point increase in the index of participation in revenues from personal income tax for 5 years.

In the analysed period, two new procedures were introduced:

- a local referendum ${ }^{5}$, introduced in 2011, based on the initiative of a minimum of 15 inhabitants. A positive result of the referendum requires the commune council to submit an application to the Council of Ministers for issuing an appropriate regulation regarding a change of boundaries;

- a 'fast track' procedure, introduced in 2018 on the 'wave' of the celebrations of the $100^{\text {th }}$ anniversary of Poland regaining its independence and the $150^{\text {th }}$ anniversary of the January Uprising. The 'fast track' procedure involves the restitution of the city status for localities located in the former Russian partition ${ }^{6}$, degraded after the fall of the January Uprising under the territorial reform introduced by the tsarist authorities in 1869-1870. The 'fast track' combines the ministerial and application procedures. The municipal council passes a resolution in the form of an appeal for "restoring city status lost as a result of the Tsar repressions", submitted to the MIAA. The Minister decides whether to launch the procedure, and applies to the commune council for issuing a relevant opinion. After consultations with residents, the commune council submits an application to the MIAA that, once approved, it is passed on to the Prime Minister.

\subsection{Granting city status}

A particular case of the change of LGU boundaries related to a change in the administrative status of localities is granting, and in practice - usually the restitution of formerly lost city status, based on the Regulation of the CM, usually occurring as a result of:

1) granting city status to a locality the territory of which is designated from the area of a rural commune. In the majority of cases, the application procedure is applied, and from 2018, for localities in the area of the former Russian partition, also the 'fast track' procedure;

\footnotetext{
${ }^{5}$ The procedure was introduced based on amendment of the Act on Local Self-Government of 26 May 2011 (Journal of Laws 2011 No. 134, Item 777). The rules and mode of conducting the referendum are stipulated in detail in the Act on Local Referendum (Journal of Laws 2000 No. 88, Item 985, as amended). The referendum is valid if it involves the participation of at least $30 \%$ of eligible voters (Art. 55(1)), and its result is conclusive if more than $50 \%$ of the votes are cast for a specific option (Art. 56(1)).

${ }^{6}$ This area covers the territories of current voivodeships: Lubelskie, Podlaskie, Świętokrzyskie, Mazowickie, Łódzkie, and parts of voivodeships: Kujawsko-Pomorskie, Wielkopolskie, Śląskie, and Małopolskie.
} 
2) the loss of city status by an urban commune in favour of the establishment of an urban-rural commune. The procedure is of purely administrative nature related to a change of the type of commune. It occurs in two stages based on the provisions of one regulation. The first stage involves revoking the city status of an urban commune on 1 January in favour of the establishment of a rural commune. At the second stage, on 1 January, the city status is granted to a city, and its area (usually considerably limited in comparison to its original surface area) is designated from the new rural commune that covers the remaining areas within the former administrative boundaries of the city.

\section{THE RESULTS OF THE CHANGES OF ADMINISTRATIVE BORUNDARIES IN 2010-2020}

\subsection{Decisions regarding a change of territorial-administrative status of LGUs}

In 2009-2019, a total of 194 decisions regarding the changes of boundaries were issued, covering $199 \mathrm{LGUs}^{7}$, and concerning: (1) the areas of entire communes, (2) the area of a cadastral region (villages, hamlets, or solectwos 8 in rural communes, less frequently city boroughs), (3) parts of cadastral regions, or (4) cadastral parcels. These included:

- 97 decisions regarding the incorporation of the areas of rural communes into cities, including one regarding a communal merger of a city county and rural commune (Zielona Góra) (commune-city variant);

- 34 annexations of the areas of rural communes into the neighbouring rural communes (commune);

- 13 annexations of the areas of cities into the neighbouring rural communes (city);

-4 incorporations of the areas of cities into the neighbouring cities (city-city), including one change in the status of a city into a city county status (Wałbrzych);

- 51 instances of granting city status to localities (new cities), including 47 through the exclusion of their area from rural communes, and 4 as a result of establishing urban-rural communes in cities areas.

The analysis of the changes within the units of different tiers indicates the following:

\footnotetext{
${ }^{7}$ The differences in the numbers of analysed cases result from the fact that eight changes of boundaries occurred based on four decisions, and one decision concerned the incorporation into a city of areas located in two rural communes.

${ }^{8}$ Sołectwo is an auxiliary unit of a rural commune. Sołectwo can cover one locality (e.g. a village or hamlet), a part of a locality, or several localities. One locality can also include several sołectwos.
} 
- 2 decisions concerned the changes of the boundaries of voivodeships (Dolnośląskie and Lubuskie, as well as Wielkopolskie and Lubuskie);

- 40 changes of the boundaries of counties and city counites;

- 157 changes of the boundaries of communes and cities 9

It should be mentioned that 16 of the analysed decisions concerned exchanges of areas within neighbouring LGUs.

\subsection{The changes of the administrative areas of LGUs}

The changes of LGU boundaries in 2010-2020 as a result of decisions issued by the CM covered a total area of $1,383.8 \mathrm{sq}$. $\mathrm{km}$. The majority of the changes concerned the incorporation of the territories of rural communes or their parts into cities (943 sq. km). More than half of them occurred in new cities. In the case of the designation of rural communes from the territories of cities, the surface area of all four cities covered by the changes (Czarna Woda in 2014, Władysławowo in 2015, Pieszyce in 2016, and Jastarnia in 2017) decreased from 138.3 to $44.5 \mathrm{sq}$. $\mathrm{km}$. Almost $1 / 4$ of the surface area was subject to a change in boundaries within neighbouring rural communes. The smallest area was covered by changes resulting from the incorporation of the territories of cities in rural communes $(1 \%)$.

Changes over the largest areas occurred within units of the $3^{\text {rd }}$ tier, and covered almost 900 sq. $\mathrm{km}$, whereas more than $63 \%$ accounted for the incorporations of the territories of rural communes into cities, and $30 \%$ - rural communes into rural communes. In the scope of $2^{\text {nd }}$ tier units, the changes covered $487 \mathrm{sq} . \mathrm{km}$. They were dominated by the incorporations of the territories of rural communes in the administrative boundaries of city counties $(68 \%$ of the area covered by a change). The smallest changes concerned the areas of voivodeships (0.05 sq. km) (Table 1$)$.

Small area changes were dominant (up to $1 \mathrm{sq} . \mathrm{km}$ ). Only $16 \%$ of the decisions were issued for areas exceeding $10 \mathrm{sq}$. $\mathrm{km}$. The changes concerning the largest areas resulted from: the restitution of the Jaśliska commune (the Podkarpackie Voivodeship) in 2010 (99 sq. km) and its later expansion in 2017 (67.2 sq. km), the change of the status of the city of Wałbrzych (the Dolnośląskie Voivodeship) to a city county in 2013 (84.7 sq. km), the merger of the city county and commune of Zielona Góra (the Lubuskie Voivodeship) in 2015 (220 sq. km), and the abolition of the Ostrowice commune (the Zachodniopomorskie Voivodeship) in 2019 $(150.6$ sq. $\mathrm{km})$ and the incorporation of its territory into the Drawsko Pomorskie (65.6 sq. km) and Złocieniec communes ( 85 sq. km).

\footnotetext{
9 'Commune' is defined as a rural commune, and an urban commune and a city in the urban-rural commune is described as a 'city'. Such a differentiation is also applied in CM Regulations.
} 
Table 1. Changes in administrative area resulting from a change in LGU boundaries in Poland in the 2010-2020 period in reference to the 3-tier territorial division of the country (in sq. $\mathrm{km}$ ) and the number of decisions issued (in \%)

\begin{tabular}{|l|c|r|r|r|}
\hline \multirow{2}{*}{ Name of unit } & \multicolumn{2}{|c|}{ Decisions } & \multicolumn{2}{c|}{ Area } \\
\cline { 2 - 5 } & Number & \% & Sq. $\mathbf{~ m}$ & \% \\
\hline Voivodeship & 2 & 1 & 1 & 1 \\
\hline County, including & 40 & 20 & 487 & 34 \\
\hline city county & 27 & 13 & 411 & 30 \\
\hline Commune, including & 157 & 79 & 896 & 65 \\
\hline commune-city & 72 & 36 & 116 & 8 \\
\hline city-commune & 9 & 4 & 15 & 1 \\
\hline commune-commune & 23 & 12 & 270 & 19 \\
\hline city-city & 2 & 1 & 1 & 1 \\
\hline new cities & 51 & 26 & 495 & 36 \\
\hline
\end{tabular}

Source: own work based on CM Regulations.

\subsection{The cyclical character of the changes of LGUs boundaries related to unit status and administrative division}

The changes of the boundaries of voivodeships in 2010-2020 were made twice, and covered a total of $0.056 \mathrm{sq}$. $\mathrm{km}$ (Table 1). The effect of the changes of boundaries was an increase in the area of the Lubuskie Voivodeship with a simultaneous reduction of the area of the Dolnośląskie (2013) and Wielkopolskie Voivodeships (2016).

The changes of boundaries between counties within $2^{\text {nd }}$-tier units even though occupied $20 \%$ of decisions and covered $34 \%$ of the area subject to change, occurred much more frequently (Table 1). They were dominated by one-off changes within neighbouring rural areas. In the case of some counties (Jarociński, Mikołowski, and Pszczyński), the changes were of cyclical nature. Moreover, changes were introduced in the boundaries of 14 city counties. Most were one-off changes involving the incorporation of the territories of the neighbouring rural communes. Annexations over the largest areas were performed in Opole $(52.3 \mathrm{sq} . \mathrm{km})$ and Koszalin (15 sq. km). Cyclical annexations occurred more seldom (10 decisions). In the analysed period, Rzeszów increased its territory the most frequently (in 2010, 2017, and 2019, a total of 28.9 sq. km was incorporated into the city), and Skierniewice and Żory at a lower scale.

The changes of boundaries within administrative units of the $3^{\text {rd }}$ tier resulted from almost $80 \%$ of decisions, and covered $65 \%$ of the area (Table 1 ). $96 \%$ of the decisions concerned urban-rural communes, and usually involved: (1) the expansion of city boundaries by the territories of neighbouring villages or hamlets, 
or (2) instances of granting city status to localities located in a rural commune. Among one-off annexations, the most spectacular ones include the expansion of the boundaries of Sędziszów Małopolski (27.0 sq. km), Otmuchów (21.7 sq. km), and Szczecinek (11.3 sq. km). Changes resulting in a part of the territory of a city annexed to a rural commune occurred considerably less often. Among those, the exclusion of villages and settlements from the boundaries of the cities of Jedwabne and Ciechanowiec, and their incorporation into neighbouring rural communities is particularly noteworthy. Only two cases of a change of the boundaries of neighbouring cities were recorded in the analysed period (Reda and Wejherowo, and Orzesze and Laziska). The changes of the boundaries of neighbouring rural communes were also usually of one-off nature, although some resulted in a large-area change (e.g. Jaśliska, Drawsko Pomorskie, Złocieniec, and Rutka-Tartak). Cyclical changes occurred considerably less often. They were primarily introduced in suburban zones (Jarocin, Żarów, and Mirosławiec). Cyclical changes in boundaries also occurred in the rural communes of Spytkowice, Pułtusk, and Kobiór.

\subsection{New (old) cities}

Another important issue in the context of the changes in administrative boundaries is the fact of granting city status to localities which results in the establishment of new cities. A total of 51 such cases were recorded in the analysed period (1/4 of the analysed decisions), whereas four concerned the establishment of urban-rural communes in the territories of cities (the aforementioned: Jastarnia, Władysławowo, Czarna Woda, and Pieszyce), and the remaining 47 were instances of extracting a city area from a rural commune. The highest number of new cities is located in the Świętokrzyskie (13) and Lubelskie (7) Voivodeships, and none in the Śląskie and Kujawsko-Pomorskie Voivodeships.

In only nine cases a locality obtained the city status for the first time (the latest being Mielno and Morawica in 2017). The majority of cases involved the restitution of the city status granted in the Middle Ages which was lost in the 1869-1870 period $^{10}$ (27 cities, including 8 based on the 'fast track' procedure: Nowy Korczyn, Oleśnica, Pacanów, Opatowiec, Klimontów, Lututów, Piątek, and Czerwińsk nad Wisłą). Lututów (the Lódzkie Voivodeship) obtained the city status already for the third time. In spite of the positive decision of the $\mathrm{CM}$, the city status has not been obtained by Chełmiec so far (the Małopolskie Voivodeship). It should be emphasised that in the analysed period the demographic criterion (over 2000 inhabitants) did not consider in as many as 26 decisions. Until 2017, such cases were rare. Since 2018, after the introduction of the 'fast track' procedure, where the fact of stripping the city status by

\footnotetext{
${ }^{10}$ Among 336 cities degraded in the period 1869-1870 currently located in the territory of Poland, 153 remain with no city status or constitute dependent parts of other cities (state as of May 2020).
} 
the tsarist authorities was crucial, it has become customary (only 4 out of 21 new cities have more than 2,000 inhabitants). In 2018, the city status was granted to cities with less than 1,000 residents (Wiślica - 550, and Józefów nad Wisłą - 920), and in 2019 the city status was regained by Opatowiec with a population of only 309 .

\subsection{The general effects of the administrative boundary changes on the territorial division of Poland}

In 2009, there were 897 cities in Poland, including 306 in urban communes, 591 in urban-rural communes, and 1,581 rural communes. The number of units of the $3^{\text {rd }}$ tier was 2,478 , and 379 in the $2^{\text {nd }}$ tier, including 314 counties and 65 city counties. In 2010-2020, as a result of the introduction of regulations of the CM regarding the changes in boundaries and granting city status, changes occurred in the number of the units of the $2^{\text {nd }}$ tier - one city county was established, and $3^{\text {rd }}$ tier - one rural commune was established (Jaśliska) and two were abolished (Ostrowice, and Zielona Góra), and the number of urban and rural communes decreased (by 4 and 47, respectively) in favour of new urban-rural communes. As a result of the aforementioned changes, the total number of units of the $3^{\text {rd }}$ tier decreased by 1 to $2,477^{11}$. In 2020 in Poland, there were 944 cities, including 302 in urban communes, 642 urban-rural communes, and 1,533 rural communes. A total of 379 changes of unit boundaries in the $1^{\text {st }}, 2^{\text {nd }}$, and $3^{\text {rd }}$ tier were introduced, where their highest number results from the incorporation of territories of rural communes into cities (Table 2).

Table 2. Changes in the administrative division of Poland in the years 2010-2020

\begin{tabular}{|c|c|c|c|c|c|c|}
\hline \multirow[b]{2}{*}{ Voivodeships } & \multirow[b]{2}{*}{ Counties } & \multirow{2}{*}{$\begin{array}{c}\text { City } \\
\text { counties }\end{array}$} & \multicolumn{2}{|c|}{ Communes } & \multirow{2}{*}{$\begin{array}{c}\text { Cities in } \\
\text { urban-rural } \\
\text { communes }\end{array}$} & \multirow{2}{*}{$\begin{array}{c}\text { New } \\
\text { urban-rural } \\
\text { communes }\end{array}$} \\
\hline & & & Rural & Urban & & \\
\hline \multicolumn{7}{|c|}{ establishment } \\
\hline- & - & 1 & 1 & - & 47 & 51 \\
\hline \multicolumn{7}{|c|}{ abolition } \\
\hline - & - & - & 1 & 4 & - & - \\
\hline \multicolumn{7}{|c|}{ change of boundaries } \\
\hline 4 & 45 & 21 & 163 & 77 & 66 & 3 \\
\hline
\end{tabular}

* The table presents the changes of boundaries of all LGUs covered by the decision of the $\mathrm{CM}$. The total number of 379 results from the fact that in approximately a dozen cases the changes concerned not only communes/cities, but also counties/city counties, and voivodeships.

Source: own work based on CM Regulations.

\footnotetext{
${ }^{11}$ In July 2015, the CM issued a regulation regarding the establishment of the Szczawa commune and the Grabówka commune (Journal of Laws Item 1085), but the new government constituted in November 2015 revoked the decisions.
} 
As a result of the establishment of urban-rural communes in the territories of cities and the annexation by rural communes of areas which used to belong to cities, 19 new villages and hamlets were established (which were restituted in the majority of cases).

\section{DISCUSSION AND CONCLUSIONS}

The analyses conducted for the 2010-2020 period, based on 194 Regulations of the Council of Ministers resulting in the changes of administrative boundaries in 199 LGUs, permitted the identification of the principal mechanisms of the transformation of the existing administrative-territorial structure and a clarification of the interactions between units subject to boundary changes. The research has highlighted several dominant trends and tendencies in each of the aspects of the discussed issue.

Firstly, Poland was in the mainstream of European territorial reforms until the 1990s. The intensification of the fragmentation of communes as a result of the deregulation of forced mergers from the 1970s (Swianewicz et al., 2016), observed in most post-socialist countries (Swianewicz, 2010; Ebinger et al., 2019) was effectively halted by the 1998 county reform. The study evidently shows that Poland is aligned with neither the consolidation (Estonia, France, and Norway) (Traves, 2018) nor the 'divorce' (Romania, Ukraine, and Slovenia) (Swianewicz, 2020) trends recently observed in Europe. New amalgamations or splits, which occurred in the 1990s and in the early 2000s, are sporadic, and their introduction is partly due to the adopted strategies. As a result of the undertaken bottom-up initiatives, the county city and commune of Zielona Góra merged (Kociuba, 2019; Swianewicz, Szmigiel-Rawska, 2020) and the commune of Jaśliska was restituted. The divisions are connected with top-down actions, i.e. the abolition of the Ostrowice commune (by virtue of the special act due to its bankruptcy caused by its indebtedness in quasi-banking entities). This affects the stable number of units within the $3^{\text {rd }}$ tier territorial division of the country.

Secondly, as in previous years, the application procedure was still prevalent ( $90 \%$ of decisions approved by the CM). The initiators of boundary changes were most often the city authorities (particularly in urban-rural communes) and city counties interested in territorial expansion (almost 50\% of decisions). Therefore, the role of the state continued to be limited to approving the municipalities' applications for boundary changes. In some cases the Council of Ministers assumed the role of the 'oracle' in a dispute between the municipalities which were to gain from the change and those which were to lose. The most prominent example was that of Opole, which expanded its boundaries in 2017 with a strong opposi- 
tion from neighbouring municipalities expressed in the negative results of public consultations and with a violation of statutory procedures, yet with strong political support (Kociuba, 2019). Moreover, the first merger procedure supported by a ministerial 'bonus' (Zielona Góra in 2015) (Kociuba, 2019; Swianewicz and Szmigiel-Rawska, 2020) was successfully completed and two new procedures for boundary changes have been introduced. The local referendum procedure was applied sporadically, and boundary changes assumed the form of small area adjustments. In contrast, the 'fast track' procedure became very popular (in 2019-2020 8 restitutions were implemented under this procedure, and in 2020, 6 localities passed appeals to the MIAA).

Thirdly, the trend of intra-commune fragmentation within $3^{\text {rd }}$-tier units has intensified. This is mainly due to the granting, and in most cases restitution, of the city status to localities in rural communes (1/4 of the analysed decisions) and the exclusion of rural communes from the territories of cities (4 cases). This has resulted in an increase in the number of cities (from 897 to 944) and urban-rural communes (from 591 to 642), and a decrease in the number of rural communes (from 1,581 to 1,533).

Fourthly, the trend of incorporating suburban areas into cities and county cities, observed since 1989 (Kaczmarek, 2016; Swianewicz et al., 2016; Szmytkie and Krzysztofik, 2019), has prevailed. In turn, the processes of the disintegration of cities artificially expanded in the socialist period, observed in the 1990s (Jarczewski, 2002; Kaczmarek, 2016; Szmytkie and Krzysztofik, 2019) were inhibited. The few cases of the secession of cities concern only tourist resorts whose inhabitants, after the change of boundaries, have the opportunity to benefit from EU funds allocated for rural development.

Fifthly, over the last 10 years, a 'new wave' (1/4 of all issued decisions) of 'new cities' has been noticed. There has been a return to the trend observed already in the 1990s (50 new cities), which stopped the implementation of the Act on the three-stage division of the state (23 new cities in the first decade of the 2000s) (Krzysztofik and Dymitrow, 2015). Two issues should be emphasised, i.e. historical-genetic and demographic. Firstly, $80 \%$ of the 'new cities' are cities that regained their city status, and the remaining ones are villages being granted city status for the first time ( 9 cases by 2017). Secondly, the demographic criterion $(2,000$ inhabitants), which was still in force in the early 2000 s, was completely abandoned (out of 47 new cities, only 18 have a population of more than 2,000, and after 2018, only one in 14 has met that criterion). This is closely related to the 'new wave of restitutions' after the introduction of the 'fast track' procedure. This trend, which has emerged as 'damage compensation in the name of historical justice', is intensifying, and it includes predominantly the smallest cities. It results from the activity of local authorities seeking opportunities to elevate their prestige and recognisability through gaining the city status, as well as quantifiable economic benefits (cities with a population below 5,000 are entitled to apply for EU subsidies for both rural and 
urban areas). The 'fast-track restitution' of cities also has significant effects for the settlement system of the country - it densifies the city network in the least urbanised regions (the Świętokrzyskie and Lubelskie Voivodeships).

Moreover, some phenomena not previously analysed in terms of unit area and frequency of boundary changes were identified. Changes in boundaries in the analysed years covered an area of $1383.8 \mathrm{sq} . \mathrm{km}$, which corresponds with the area of 6 largest cities in Poland (Warsaw, Krakow, Łódź, Wrocław, Poznań, and Gdańsk). Small area changes prevailed (more than $50 \%$ of the decisions concerned areas below $1 \mathrm{sq} . \mathrm{km}$ ). Large area changes primarily resulted from fusions, fragmentations, and the establishment of a commune, as well as designation of a county city. They constituted a total of $45 \%$ of the total area subject to change. A further $35 \%$ of the area constitutes new cities. In the hierarchical layout, changes covering the largest areas occurred within $3^{\text {rd }}$ tier units ( $65 \%$ of the area subject to change), and primarily resulted from the establishment of new cities, or territorial annexations in urban-rural communes. As a consequence, rural communes lost territories and cities gained them ( $70 \%$ of the area subject to change). In the case of $2^{\text {nd }}$-tier units, increases in territory of county cities were dominant. The greatest stability was confirmed for boundaries of voivodships.

Most of the changes in boundaries were of a one-off adjustment nature $(80 \%$ of decisions). This regularity concerned both units of the same tier and units in the hierarchical system. Cyclical changes were considerably rarer, and primarily concerned expansion of the boundaries of cities or city counties. The peculiar record-holder was the city of Rzeszów which increased its territory by $30 \%$ as a result of three expansions of its boundaries.

Finally, it should be emphasises that the phenomenon of the politicisation of the process of boundary changes was observed. In extreme cases, boundary changes or the restitution of the city status did not reflect the needs of local communities and elites, but became part of the political game. The best known case was the incorporation of a highly profitable power plant into the city of Opole. In addition to numerous revolts and protests of residents of the annexed areas, it led the Dobrzeń Wielki commune to the verge of bankruptcy as it was deprived of investment income in violation of the law, but with a vast support of political elites (Kociuba, 2019). Such politicisation was especially noticeable in the years preceding the local government elections held in 2010, 2014, and 2018. At that time, out of approximately 30 applications submitted annually, the majority were approved. In 2009, the number was 26; the 28 in 2014, 17 in 2017, but as many as 29 in 2018, including 10 concerning the granting of city status, four of them within the 'fast track' procedure. It should also be mentioned that this regularity did not apply to the years of parliamentary $(2011,2015,2019)$ or presidential elections $(2010,2015,2020)$, when the CM approved approximately 10-15 applications. The intensification of the politicisation of the process of boundary changes was particularly evident with the introduction of the 'fast track' procedure in 2018. The support of commune 
authorities in the restitution of city status was used by many local politicians as a basis for building electoral capital in their local government election campaigns. The 'new wave of restitution' has not been weakening, which in the context of the upcoming local elections (2022) requires in-depth studies.

\section{REFERENCES}

BALDERSHEIM, H. and ROSE, L. (eds.) (2010), Territorial choice: The politics of boundaries and borders, Basingstoke: Palgrave-Macmillan.

BLOM-HANSEN, J., HOULBERG, K. and SERRITZLEW, S. (2014), 'Size, Democracy, and the Economic Costs of Running the Political System', American Journal of Political Science, 58 (4), pp. 790-803. https://doi.org/10.1111/ajps.12096

CARR, J. B. and FEIOCK, R. C. (2016), City-County Consolidation and Its Alternatives. Reshaping the Local Government Landscape, Routledge. https://doi.org/10.4324/9781315705644

CHOJNICKI, Z. and CZYŻ, T. (2000), 'Nowa organizacja terytorialna Polski i układ regionalny', Czasopismo Geograficzne, 3-4, pp. 263-277.

DROBEK, W. (2002), 'Polskie nowe miasta 1977-2001', [in:] SŁODCZYK, J. (ed.), Przemiany bazy ekonomicznej i struktury przestrzennej miast, Opole: Uniwersytet Opolski, pp. 71-84.

EBINGER, F., KUHLMANN, S. and BOGUMIL, J. (2019), 'Territorial reforms in Europe: effects on administrative performance and democratic participation', Local Government Studies, 45 (1), pp. 1-23. https://doi.org/10.1080/03003930.2018.1530660

HARDY, P. (2012), The Consolidation of City and County Governments: A Look at the History and Outcome-Based Research of These Efforts, The University of Tennessee.

HOLZER, M., FRY, J., CHARBONNEAU, E., RICCUCCI, N., HENDERSON, A., KWAK, S. and BURNASH, E. (2009), Literature Review and Analysis Related to Municipal Government Consolidation, Newark, NJ: Rutgers-Newark School of Public Affairs and Administration.

JANICKI, W. (2020), 'Contemporary administrative division and historically shaped regional borders: a comparative analysis in Poland', Human Geographies - Journal of Studies and Research in Human Geography, 14 (1), pp. 39-58. https://doi.org/10.5719/hgeo.2020.141.3

JARCZEWSKI, W. (2002), Odzyskana niezależność. Przyczyny i skutki powstania nowych gmin na obrzeżach GOP w latach 90., Kraków: Wydawnictwo Dante.

KACHNIARZ, M. (2016), 'Fuzja miasta i powiatu - przegląd doświadczeń międzynarodowych', Studia i Prace WNEiZ US, 46 (2), pp. 45-55. https://doi.org/10.18276/sip.2016.46/2-04

KACZMAREK, T. (2001), 'Reforma terytorialno-administracyjna Polski - porównanie z krajami Unii Europejskiej', Biuletyn KPZK PAN, 197, pp. 131-155.

KACZMAREK, T. (2005), Struktury terytorialno-administracyjne i ich reformy w krajach europejskich, Poznań: Wydawnictwo Naukowe UAM.

KACZMAREK, T. (2016), 'Gminny podział administracyjny w świetle 25 lat funkcjonowania samorządu terytorialnego w Polsce', Przegląd Politologiczny, 1, pp. 63-80. https://doi.org/ 10.14746/pp.2016.21.1.5

KOCIUBA, D. (2019), 'Zmiany granic administracyjnych miast w Polsce - efekty przestrzenne i społeczno-ekonomiczne', Studia Miejskie, 33, pp. 99-113. https://doi.org/10.25167/sm.1253

KONECKA-SZYDŁOWSKA, B., TRÓCSÁNYI, A. and PIRISI G. (2018), 'Urbanisation in a Formal Way? The Different Characteristics of the 'Newest Towns' in Poland and Hungary', Regional Statistics, Journal of the Hungarian Central Statistical Office, 8 (2), pp. 135-153. https://doi. org/10.15196/RS080202

KRZYSZTOFIK, R. and DYMITROW, M. (eds.) (2015), Degraded and restituted towns in Poland: Origins, development, problems, Gothenburg: University of Gothenburg. 
KULESZA, M. (1997), 'Reforma podziału administracyjnego Polski', [in:] SWIANIEWICZ, P. (ed.) Wartości podstawowe samorządu terytorialnego i demokracji lokalnej, Warsaw: Municipium, pp. 240-252.

LADNER, A., KEUFFLER, N., BALDERSHEIM, H., HLEPAS, N., SWIANIEWICZ, P., STEYVERS, K. and NAVARRO, C. (2019), Patterns of local autonomy in Europe, London: Macmillan. https://doi.org/10.1007/978-3-319-95642-8

LISZEWSKI, S., GRYSZKIEWICZ, J. and KACZMAREK, S., (1989), 'Nowe miasta jako przedmiot badań naukowych'. Acta Universitatis Lodziensis, Folia Geographica, 11, pp. 257-279.

MAGONE, J. M. (ed.) (2003), Regional Institutions and Governance in the European Union, Westport, CT: Praeger.

MISZCZUK, A. (2003), Regionalizacja administracyjna III Rzeczpospolitej. Koncepcje teoretyczne a rzeczywistość, Lublin: Wydawnictwo Uniwersytetu Marii Curie-Skłodowskiej.

RAJCHEL, D. (2018), 'Zmiana granic administracyjnych miasta metodą pokonania bariery przestrzennej na przykładzie Opola i Rzeszowa'. [in:] SITEK, S. (ed.) „Stare i nowe” problemy badawcze w geografii społeczno-ekonomicznej, 8, Sosnowiec: Uniwersytet Śląski, Wydział Nauk o Ziemi, Polskie Towarzystwo Geograficzne Oddział Katowicki, pp. 85-102.

SŁUŻEWSKI, J. (1977), Terenowe organy administracji i rady narodowe po reformie, Warsaw.

SOBOTA, M., JAWECKI, B. and TOKARCZYK-DOROCIAK, K. (2012), 'Aspekty prawne zmiany granic administracyjnych gmin', Barometr Regionalny, 4 (30), pp. 31-38.

SOKOŁOWSKI, D. (2014), 'New Towns in Poland', Bulletin of Geography, Socio-Economic Series, 23, pp. 149-160. https://doi.org/10.2478/bog-2014-0010

STEINER, R., KAISER, C. and EYTHÓRSSON, G. T. (2016), 'A Comparative Analysis of Amalgamation Reforms in Selected European Countries' [in:] KUHLMANN, S. and BOUCKAERT, G. (eds.) Local Public Sector Reforms in Times of Crisis, London: Palgrave, pp. 23-43. https://doi. org/10.1057/978-1-137-52548-2 2

SWIANIEWICZ, P. (ed.) (2002), Consolidation or Fragmentation? The Size of Local Governments in Central and Eastern Europe, Budapest: Open Society Institute.

SWIANEWICZ, P. (2020), 'Municipal divorces - the under researched topic of territorial reforms in Europe', Acta Geobalcanica, 6-1, pp. 27-33. https://doi.org/10.18509/AGB.2020.03

SWIANIEWICZ, P., GENDŹWIŁŁ, A., KURNIEWICZ, A. and ŁUKOMSKA, J. (2016), Wielkość gmin i powiatów a sprawność ich funkcjonowania: hipotezy wielkoludów i liliputów, Warsaw: Wydawnictwo Naukowe Scholar.

SWIANIEWICZ, P., GENDŹWIŁŁ, A. and ŁUKOMSKA J. (2018), 'Inicjatorzy i opuszczeni: demokracja lokalna po gminnych «rozwodach»'. Prace Geograficzne, 154, pp. 7-33. https:// doi.org/10.4467/20833113PG.18.010.9442

SWIANIEWICZ, P. and SZMIGIEL-RAWSKA, K. (2020), 'Why some local governments choose not to free-ride when undergoing boundary reform: a study of two merger cases in Poland', Local Government Studies, pp. 1-22. https://doi.org/10.1080/03003930.2020.1761337

SZMYTKIE, R. (2014), 'Procesy inkorporacji i secesji miast w Polsce po 1945 r.', [in:] KUĆ-CZAJKOWSKA, K. and SIDOR, M. (eds.), Miasta, aglomeracje, metropolie $w$ nurcie globalnych przemian, Lublin: Wydawnictwo Uniwersytetu Marii Curie-Skłodowskiej, pp. 177-200.

SZMYTKIE, R. and KRZYSZTOFIK, R. (2019), 'The processes of incorporation and secession of urban and suburban municipalities: The case of Poland', Norsk Geografisk Tidsskrift-Norwegian Journal of Geography, 73 (2), pp. 110-127. https://doi.org/10.1080/00291951.2019.1604567

SZYMAŃSKA, D. (1993), New towns in regional development, Toruń: Wydawnictwo Uniwersytetu Mikołaja Kopernika.

SZYMAŃSKA, D., GRZELAK-KOSTULSKA, E. and HOŁOWIECKA, B. (2009), 'Polish towns and the changes in their areas and population densities', Bulletin of Geography: Socio-economic Series, 11, pp. 15-30. https://doi.org/10.2478/v10089-008-0018-2

WALCZAK, D. (2012), 'Konieczność zmian w podziale terytorialnym gmin', Zeszyty Naukowe SGGW, Ekonomika i Organizacja Gospodarki Żywnościowej, 99, pp. 205-213. 